\title{
Biotech bubbles during the global recession
}

Private biotech firms are awash with funding, raising record-breaking sums in 2020. Melanie Senior reports.

iggest. Best. Worst. Deepest. Almost any superlative you like will probably fit 2020. It was a year that smashed many records. The most important was producing approved vaccines less than 12 months after an entirely new pathogen was sequenced.

Fundraising across the biotech sector rocketed off the charts. Biotech's savior role in the pandemic attracted a stampede of private and public investors alike-including some deep-pocketed newcomers. Venture financing hit an all-time high of over $\$ 23$ billion-up over $60 \%$ on an already strong 2019 (Fig. 1). More than \$11 billion worth of new biotech funds were raised. Some companies had secured their investments in 2019, but plenty more were able to capitalize on the surge in interest during the year (Table 1). Initial public offerings (IPOs) pulled in nearly three times as much as in the previous year, and over half were preclinical or phase 1 companies. Biotech stock indices all rose strongly.

In short, the global recession apparently passed biotech by. The cash wasn't only backing companies developing COVID-19 vaccines or therapies-though many in this group benefited. Instead, the pandemic apparently "reinforced the requirement for long-term, value-based investors of any kind to have exposure to life sciences, including biotech," says Shahzad Malik, general partner at Advent Life Sciences.

\section{Mega-rounds}

For the few private companies working on infectious disease products, 2020 brought an inevitable COVID-19-linked bonanza. Tübingen, Germany-based CureVac, whose unmodified mRNA-based vaccine candidate for COVID-19 is in phase $2 b / 3$, raised over $\$ 600$ million in July, including a loan from the German government, and a further \$245 million when it listed on Nasdaq a month later. Overall, the pandemic triggered an almost doubling of precommercial deals involving private infectious diseases companies, but this was from a low baseline of only 10 deals or fewer each year since 2010. Financing also spiked in 2020 , reaching over $\$ 670$ million-still not close to the $\$ 3.5$ billion raised by cancer companies (Fig. 2).

Outside infectious disease, the pre-crisis trend toward ever-larger private financing rounds accelerated sharply in 2020 . The
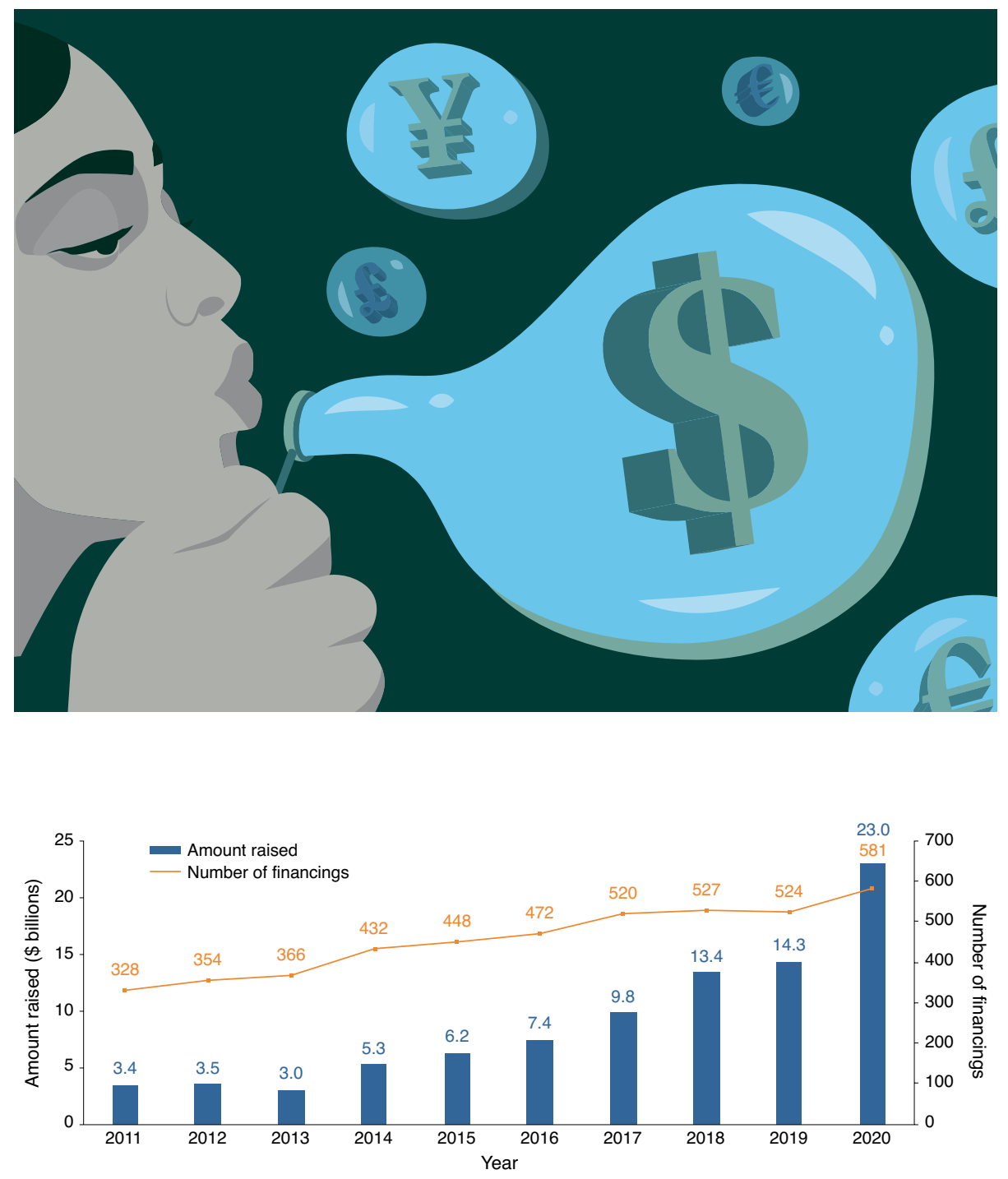

Fig. 1 | Global VC investment in biotech over ten years. Source: BCIQ.

$\$ 23$ billion total included 58 rounds of over $\$ 100$ million-more than double 2019's tally-and eight private rounds worth over \$250 million (Table 2).

Those eight mega-raises reinforce existing themes that became prominent in 2020: the advance of cell and gene therapy, gathering momentum in precision oncology and the rise of innovative R\&D in China. The emergence of cell and gene therapy modalities is likened to the arrival of replacement proteins and monoclonal antibodies (mAbs). "People are buying into these [cell or gene] technologies not for their potential in narrowly defined, monogenic diseases alone, but for their potential well beyond that" in much more widespread conditions, says Jeffrey Tong, partner at Third Rock Ventures. Third Rock is an investor in another of 2020's top-ten private fundraisers, liquid biopsy group Thrive Earlier Detection (Box 1).

Sana Biotechnology's $\$ 700$ million was aggregated funding raised since the company came onto the radar in 2019. Never mind that the Seattle-based 
Table 1 | New money flowing into biotech

\begin{tabular}{ll} 
Fundraiser & Amount raised, \$ millions (date announced) \\
\hline Frazier Healthcare Partners & 617 (January 16) \\
\hline Andreessen Horowitz & 750 BioFund III (February 4) \\
New Enterprise Associates & $3,600^{\circ}$ (March 11) \\
\hline Flagship Pioneering & 1,100 (April 2) \\
Arch Venture Partners & $1,460^{b}$ (April 2) \\
VenBio & 394 (April 3) \\
Gilde & 450 Gilde Healthcare V (April 3) \\
Deerfield Management & 840 (April 6) \\
Qiming Venture Partners & 1,100 (April 9) \\
Kurma Partners & 173 (April) \\
TVM Capital Life Science & 478 (October) \\
Peregrine Ventures & $300^{\circ}$ (October) \\
Forbion & 560 (December) \\
\hline
\end{tabular}

Table shows selected new funds announced in 2020 . ${ }^{\mathrm{T} T e c h n o l o g y}$ and healthcare. ${ }^{\mathrm{b}}$ Total across two funds targeting early-stage biotechs. cPlanned size; \$101 million closed as of October 2020.

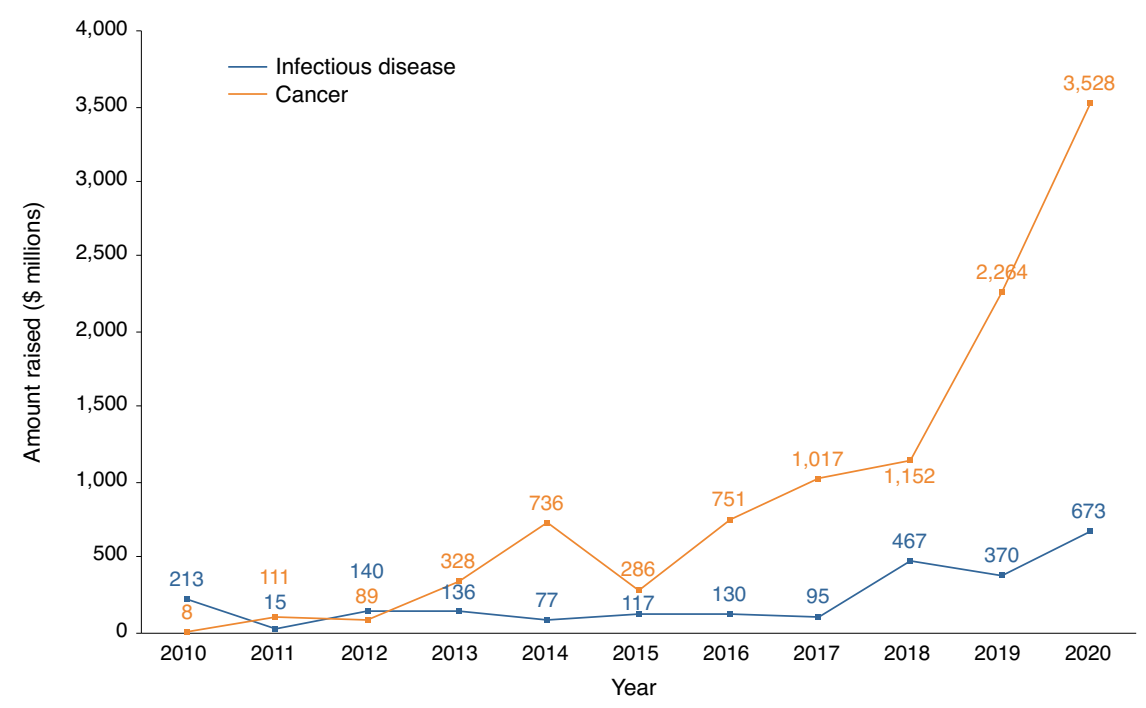

Fig. 2 | Infectious diseases activity rises, but still in cancer's shadow. Source: BCIQ.

company's suite of (mostly) cancer-focused cellular therapies is still preclinical. Seasoned management (the company being run by Juno Therapeutics alumnus Steve Harr) and the apparently boundless promise of engineered cells was enough to draw in a range of investors-and propel the company to a $\$ 587.5$ million IPO in January 2021. For the listing, familiar biotech names like founding venture capital (VC) firm Flagship Pioneering and Arch Ventures were joined by a trail of lesser-known backers such as the Canada Pension Plan Investment board and UK investment management firm Baillie Gifford.
Three-year-old cell therapy specialist Lyell Immunopharma's bumper $\mathrm{C}$ round also reflects its team's track record: founder Rick Klausner is another Juno veteran and former US National Cancer Institute head. Lyell hasn't gone public, yet, but the South San Francisco-based company has used some of its funds to invest alongside traditional VCs in a suite of T-cell-focused technology partners, including Eureka Therapeutics and CERo Therapeutics.

Financings of this scale, and speed, for early-stage ventures would not have been possible just a few years ago. They have raised eyebrows among some investors, who caution about overhyping of immature technologies and the potential impact on confidence (if things don't work) and the prices of any eventual products (if they do). "If you have a big name [with a track record], you can raise large amounts of capital with just a sketch on the back of a napkin," quips one investor, preferring to remain anonymous.

Yet the deepening of biotech capital markets-now a multiyear trend- "has structural implications for the sector's ability to raise capital and scale enterprises," argues Bruce Booth, partner at Atlas Venture. In other words, all this money is fast-forwarding biotech's innovation cycle, allowing parallel shots on goal. "Better funded companies have more scope to make mistakes, dust themselves off and try again," comments Malik.

That argument held, apparently, for 2020's series A financing rounds, seven of which were worth over $\$ 100$ million. The average series A round size- $\$ 34$ millionwas almost $30 \%$ larger than in 2019. Five of those top A-rounders focus on gene or cell therapy or precision oncology.

\section{China boosts outsized A rounds}

Chinese companies, investors and markets also became more prominent during 2020. Nearly a third of the $\$ 100$-million-plus private rounds of 2020 were raised by Chinese companies - up from just a seventh in 2019. Shanghai-based Mabwell Bioscience and D3 Bio raised the two largest A rounds anywhere (Table 3 ). This reflects the country's burgeoning investment in more innovative biotechs, as well as the economy's more rapid return to normality following the SARS-CoV-2 outbreak. Mabwell has assembled more than 30 assets-mostly mAbs and long-acting recombinant proteins-for oncology, autoimmune disease, infectious disease and ophthalmology; three are in phase 3 trials. D3Bio is developing an as-yet unspecified pipeline of small- and large-molecule therapies in precision medicine approaches for poorly served patient populations in oncology and immunology.

\section{New investors on the block}

Boston-based Scorpion Therapeutics' \$108 million series A illustrates once again how new investors-hedge funds, private equity firms, family offices and later-stage asset management groups, many with little or no sector experience-are willing to bet on seasoned biotech entrepreneurs running high-risk companies that may not even be in the clinic. Scorpion-whose CEO and cofounder Gary Glick started First Wave Bio and IFM Therapeutics, which made 
Table 2 | Largest private biotech funding rounds in 2020

\begin{tabular}{llll} 
Company & \$ millions raised (round) & Focus area & Country \\
\hline Sana Biotechnology & 700 (unspecified) & Gene and cell therapy & US \\
CureVac & 634 (series B) & mRNA therapies and vaccines & Germany \\
Lyell Immunopharma & 493 (series C) & Cell therapy & US \\
Grail & 390 (series D) & Cancer diagnostics & US \\
LianBio & 310 (unspecified) & & China \\
Mabwell Bioscience & 279 (series A) & Antibodies & China \\
Freenome & 270 (series C) & Cancer diagnostics & US \\
Thrive Earlier Detection & 257 (series B) & Cancer diagnostics & US \\
\hline
\end{tabular}

Table excludes China's Everest Medicines, considered specialty pharma. Source: BCIQ (includes devices, diagnostics). aSince gone public. Includes $\$ 343$ million from German government and \$171 million from GlaxoSmithKline, announced earlier.

Table 3 | 2020's largest series A rounds

\begin{tabular}{llll} 
Company & \$ millions raised & Focus area & Country \\
\hline Mabwell Bioscience & 278.5 & Antibodies & China \\
D3Bio & 200 & Precision oncology, immunology & China \\
EQRx & 200 & Low-cost therapies & US \\
Legend Biotech & 150.5 & T cell cancer therapies & China \\
Neogene Therapeutics & 110 & T cell cancer therapies & US \\
Scorpion Therapeutics & 108 & Precision oncology & US \\
AavantiBio & 107 & Gene therapy & US \\
\hline
\end{tabular}

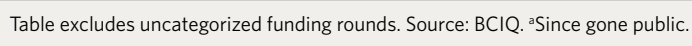

\section{Box 1 | Early detection in the money}

Diagnostics has traditionally had to feed off scraps. But several biotechs seeking to detect cancer earlier attracted eye-popping funding normally associated with cancer treatments. Grail, Freenome and Thrive Earlier Detection together raised over $\$ 900$ million from backers, including big tech, health systems and pension plans-reflecting the touted

$\$ 4$ billion on asset sales to big pharmais hunting next-generation precision oncology treatments using a suite of target identification and drug design technologies. It has yet to name its first development candidate. Still, the company barely had time to spend the series A funds raised in late 2020 from familiar biotech VC names, including Atlas Venture, Omega Funds and Vida Ventures, before an oversubscribed \$162 million series B on 7 January 2021. That round featured global equities management group Surveyor Capital, the hedge fund Woodline Partners, and investment firm Janus Henderson.

Perceptive Advisors, a New York-based hedge fund and credit provider mostly impact early detection could have on treatment outcomes and costs. Grail's $\$ 390$ million raise would have been a precursor to an IPO, had not Illuminafrom which Grail spun out five years earlier-come along with an $\$ 8$ billion check in September. The following month, Exact Sciences paid $\$ 1.7$ billion up front for Thrive.

invested in public opportunities, was part of the syndicate providing \$107 million to Cambridge, Massachusetts-based gene therapy group AavantiBio, created in October 2020. Other investors include listed gene therapy player Sarepta Therapeutics. Aavanti is using gene transfer and gene editing capabilities to build scalable, efficiently manufactured gene therapies for rare diseases, including Friedreich's ataxia, a progressive genetic neuromuscular disease. Its lead candidate for this disorder has yet to reach the clinic. Also joining was RA Capital Management, an increasingly familiar name in private biotech investing since its inaugural \$300 million venture fund was raised in 2019. RA raised a second
$\$ 461$ million private biotech fund in October 2020 (Fig. 3).

Are the newcomers here to stay? "Undoubtedly, there will be some tourists," says Tong. Some may be spooked by inevitable clinical failures and lack the courage to stay in the sector. Others may switch back to more familiar terrain, like airlines or hospitality, once those sectors recover. "The moment there are better returns available elsewhere, the [non-traditional] investors will leave," says one biotech specialist.

For now, though, biotech remains very rosy relative to most other sectors. Tong and Booth argue that most newcomers to the field, taking on more scientific risk, are following the 'smart money' and are in for the longer term. And even if some do bail out early, "the core specialist investors in biotech have grown in number and in scale, which bodes well," comments Booth.

\section{Seedlings suffer}

The rate of startup creation slowed in 2020, as might be expected during an economic lockdown. Seed and series A rounds accounted for just $28 \%$ of all private financing in 2020 , down from $35 \%$ in 2018. Total seed funding in 2020 fell to $\$ 292$ million, from \$343 million in 2019, even though the lower number of deals (64 versus 79) pushed up the average seed round size to just over $\$ 4.5$ million.

Some investors shrug off this slowdown, which began in the last half of 2019. Biotech company creation "is still at strong levels, and capital flows are enormous" for seed and series A rounds, says Booth. Third Rock's Tong says that their early-stage pipeline is full and that company creation remains steady. The continued growth of company-builder VC firms like Third Rock, as well as Arch Venture Partners, Syncona and, more recently, Deerfield Management and Hong Kong-based Nan Fung Life Sciences (part of Nan Fung Group), is a net positive: facilities and money are available for aspiring scientist-entrepreneurs. Yet it also concentrates biotech incubation in hands of the few.

There's little doubt that many newcomer entrepreneurs, lacking broad networks, have struggled to get off the ground during the year-long lockdown. "We stayed away from first-time entrepreneurs," admits one investor. The year did see some new seed investors, including Eir Ventures, which raised an $\$ 87$ million Nordic-focused fund in July. But as established investors put more money into fewer opportunities, they potentially narrow the range of innovation being funded. This could damage the 


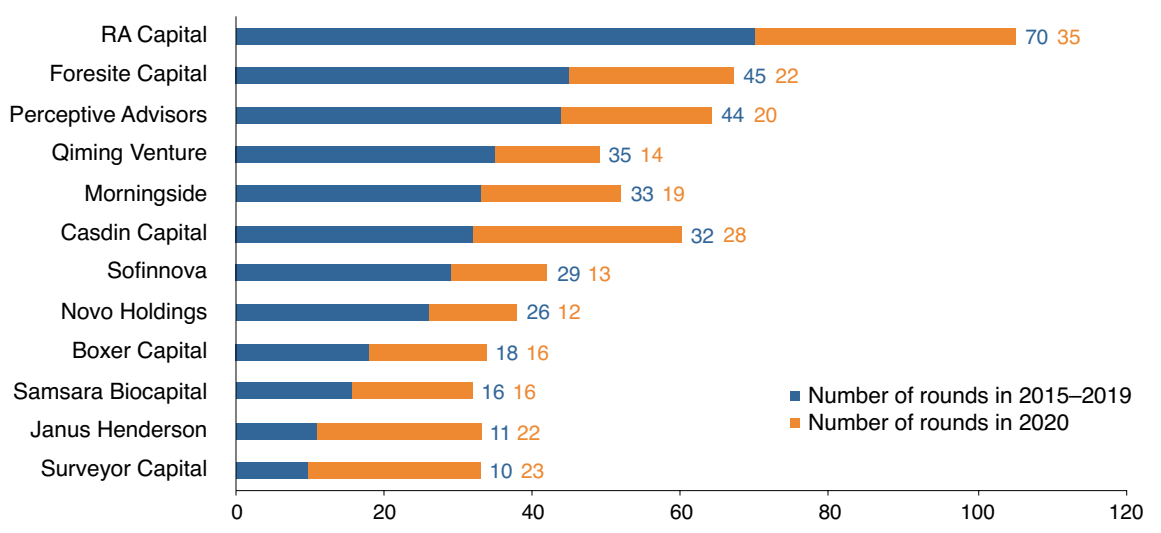

Fig. 3 | Investors whose $\mathbf{2 0 2 0}$ activity reached $\mathbf{4 0 \%}$ or more of $\mathbf{2 0 1 5 - 2 0 1 9}$ activity combined. Source: BioCentury (https://www.biocentury.com/article/633658).

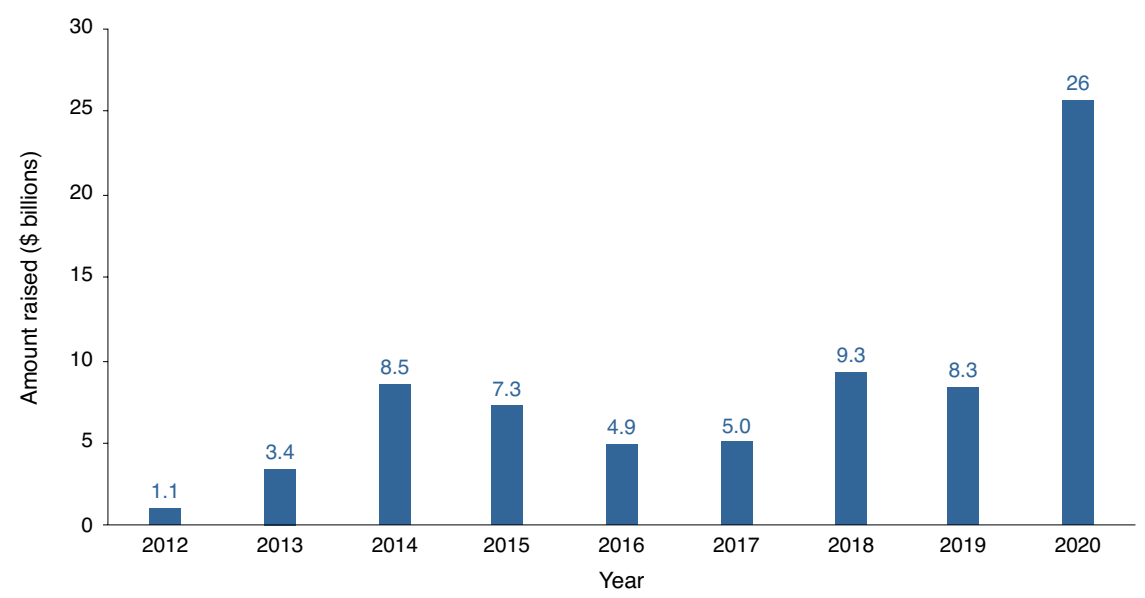

Fig: 4 | Global 2020 biotech IPOs. Source: BCIQ.

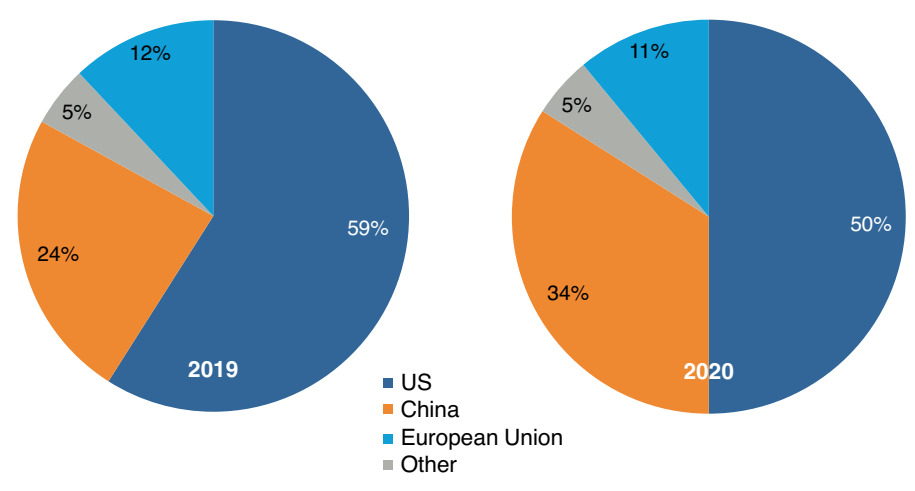

Fig. 5 | Biotech 2020 IPOs by region. Source: BCIQ.

breadth and diversity of innovation-and innovators-over the middle to long term. "I do think there is cause for worry," says one investor. But not immediately. and less tough on the shoe leather," says one investor. Listings that had tried and failed in 2019 (itself a strong IPO year) happened more easily in 2020.

The result: a global biotech IPO glut of over $\$ 26$ billion, more than three times the $\$ 8.3$ billion raised a year earlier (Fig. 4 ). The lion's share of that was still in the United States, but Chinese IPOs increased their share of the global tally from a quarter in 2019 to over a third in 2020 (Fig. 5).

Relay Therapeutics' $\$ 460$ million listing in July was the United States' biggest IPO, again showcasing the apparently insatiable appetite for precision oncology and rare genetic diseases, however early. (Relay's most advanced program is in phase 1.) These same areas drove a \$514 million Hong Kong IPO for Yantai, China-based RemeGen-the region's second-largest listing, after the $\$ 798$ million haul of Pangyo, South Korea-based SK Biopharmaceuticals, whose programs focusing on the central nervous system and cancer are approaching registration in China.

Europe-based companies still accounted for a tiny minority of IPOs and continued to favor US listings over domestic ones. The top three European biotech IPOs were all on US exchanges. Switzerland's antibody-drug conjugate developer ADC Therapeutics pulled in $\$ 267$ million on the NYSE in May, having cancelled a 2019 attempt on Nasdaq, and small-molecule and antibody immune-oncology developer iTeos Therapeutics, based in Gosselies, Belgium, gained almost $\$ 230$ million (Table 4).

Gene-therapy-focused Freeline Therapeutics, based in Stevenage, was one of only two UK-based biotechs to list in the 2020 boom. The other was London-based Compass Pathways, whose October Nasdaq listing reflects the flourishing interest in psychedelic medicines to address mental health disorders. Compass's psilocybin, a psychoactive substance found in 'magic mushrooms', is in phase $2 \mathrm{~b}$ trials; the company raised $\$ 80$ million in April 2020 in one of the largest private rounds in this emerging, but still controversial, sector.

Public market buoyancy, already evident in 2019, catalyzed wily investors to create more than 30 special-purpose acquisition companies (SPACs) - shell companies built to enable private biotechs or biotech assets to access public investors more cheaply and faster than a conventional IPO. Among them were RA Capital's aptly named Therapeutics Acquisition, which raised $\$ 118$ million in July 2020, and EcoR1's Panacea Acquisition, which raised $\$ 125$ million in June.

By October 2020, Panacea had found its biotech filling: cancer-focused Nuvation Bio, 
Table 4 | Top ten IPOs by European-based biotechs in 2020

\begin{tabular}{lll} 
Company (headquarters) & IPO size, \$ million (listing venue) & Focus area \\
\hline ADC Therapeutics (Epalinges, Switzerland) & 267 (NYSE) & Antibody-drug conjugates for cancer \\
CureVac (Tübingen, Germany) & 245 (Nasdaq) & RNA vaccines and cancer therapies \\
iTeos Therapeutics (Gosselies, Belgium) & 230 (Nasdaq) & Immuno-oncology \\
\hline ALX Oncology Holdings (Dublin, Ireland) & CD47-blocking checkpoint inhibitors (cancer) \\
\hline Freeline Therapeutics Holdings (Stevenage, UK) & 185 (Nasdaq) & AAV-based gene therapy \\
\hline Compass Pathways (London, UK) & 146 (Nasdaq) & Psilocybin-based therapy for depression \\
\hline Nyxoah (Mont-Saint-Guibert, Belgium) & 87 (Euronext Brussels) & Neuromodulation for sleep disorders \\
\hline Galecto (Copenhagen, Denmark) & 85 (Nasdaq) & Galectin-3 inhibitor for fibrosis \\
\hline Hyloris Pharmaceuticals (Liège, Belgium) & 69 (Euronext Brussels) & Reformulation \\
\hline Prostatype Genomics (Solna, Sweden) & 4 (Nasdaq Nordic) & Gene-based test for prostate cancer \\
\hline
\end{tabular}

Source: $\mathrm{BCIQ}$. ${ }^{\mathrm{F}}$ founded as Alexo Therapeutics in Dublin, Ireland; headquartered in Burlingame, California, since 2020.

\section{Table 5 | Top private biotech M\&A, ranked by up-front cash}

\begin{tabular}{llll} 
Target & Acquirer & Up-front value (\$ millions) & Therapy area \\
\hline VelosBio & Merck & 2,750 & Cancer \\
\hline Asklepios BioPharmaceutical & Bayer & 2,000 & Genetic disorders (gene therapy) \\
\hline Corvidia Therapeutics & Novo Nordisk & 725 & Cardio-renal disorders \\
\hline Inflazome & Roche & 450 & Inflammation \\
\hline KaNDY Therapeutics & Bayer & 425 & Women's health and endocrine disorders \\
\hline Tizona Therapeutics & Gilead & Cancer \\
\hline Pionyr Immunotherapeutics & Gilead & 300 & Cancer \\
\hline Disarm Therapeutics & Eli Lilly & 275 & Neurology \\
\hline lota Biosciences & Astellas & 135 & Bioeletronic diagnostic devices \\
\hline Engage Therapeutics & UCB & 127.5 & Neurology \\
\hline Blueprint Genetics & Quest Diagnostics & 125 & Rare disease diagnostics \\
\hline Orphan Technologies & Retrophin & 108 & Rare diseases (enzyme replacement therapy) \\
\hline
\end{tabular}

Source: BCIQ a Gilead bought $49.9 \%$ stake with option to buy remainder; plus milestones.

run by seasoned biotech leader David Hung. (Hung founded and led Medivation, bought by Pfizer for $\$ 14$ billion in 2016.) The merged group pulled in another half-billion dollars from an increasingly familiar mix of investor-types, including hedge fund 683 Capital Management and private equity firms Deerfield Management and Redmile Group. Nuvation's lead compound, a cyclin-dependent kinase (CDK)-2/4/6 inhibitor, is on the cusp of a clinical trial in patients with glioblastoma.

The SPAC craze - which spans industry sectors-has also reached consumer genetic testing company 23andMe, which this year plans to merge with VG Acquisition, a SPAC set up by British entrepreneur Richard Branson. The deal will bring over $\$ 750$ million in cash and value the company at $\$ 3.5$ billion. 23andMe has yet to turn a profit from its DNA testing service; its value stems from its growing collection of human genome data and an R\&D partnership with GlaxoSmithKline.

\section{Dealmaking goes online}

Dealmaking was also apparently untouched by physical lockdowns. Private biotechs signed over 200 licensing deals for preapproval assets, with combined up-front commitments worth over $\$ 1.1$ billion (not counting the majority of deals whose values are undisclosed). Remarkably, there were more deals in 2020 than in 2019-though the up-front totals didn't quite match the previous year's $\$ 1.5$ billion.

Cancer assets accounted for almost half 2020's deals, followed more closely than in 2019 by infectious diseases, with neurological and autoimmune disorders a distant third and fourth. Atop the licensing deal chart was consummate dealmaker Dragonfly Therapeutics, whose natural-killer-cell-based immunotherapy platform has already attracted three big pharma partners. In July, Bristol Myers Squibb paid \$475 million up front for a modified version of Dragonfly's inflammatory cytokine IL-12 for various cancers; this was the third deal in a partnership that began when Celgene (since acquired by Bristol Myers Squibb) tied up with the six-year-old Cambridge, Massachusetts-based biotech in 2017. Second was Relay Therapeutics (also top of the US IPO charts), which licensed its early-clinical oncology asset RLY-1971-a small molecule SHP-2 (Src homology region 2 domain-containing phosphatase-2) inhibitor-to Roche's Genentech for $\$ 75$ million up front in the closing weeks of 2020. Roche plans to test the asset in combination with in-house candidates.

\section{Private biotechs top M\&A ranks}

Three of the biggest mergers and acquisitions (M\&A) deals of 2020 in terms 


\section{Box 2 | The A-round outlier?}

EQRx stands out among 2020's largest A round fundraisers. Rather than seeking new precision oncology drugs or gene therapies, EQRx wants to lower drug prices through more efficient R\&D and through strategic tie-ups with payers and health systems. Some of those payers joined a $\$ 500$ million series B round in January 2021, alongside the high-profile tech and biotech VCs that supported the group's
$\$ 200$ million A round-the third largest of 2020.

A less promising development in the move to lower healthcare costs was the demise, announced early 2021, of JPMorgan Chase/Amazon/Berkshire Hathaway's Haven venture. Three years ago, Haven promised to squeeze out US health system inefficiencies and lower costs - a mission that proved too complex for even these heavyweight backers. of committed, up-front cash involved private companies, with yet more starring roles for gene therapy and cancer.

Merck's November 2020 buyout of partner VelosBio was the richest (Table 5). VelosBio's main prize is an antibody-drug conjugate targeting tyrosine-like orphan receptor 1 (ROR1); the candidate is in early clinical trials for previously treated liquid and solid tumors. Next largest in the private ranks, and third largest among all M\&As in 2020, was Bayer's $\$ 4$ billion buyout of gene-therapy pioneer AskBio in October 2020; the deal included $\$ 2$ billion up front. AskBio had been preparing for its IPO when Bayer approached.

Deal-shy Novo Nordisk's $\$ 2.1$ billion buyout of private Corvidia Therapeutics, based in Waltham, Massachusetts, also made it into top ten, with $\$ 725$ million committed up front, marking the Danish company's move beyond price-pressured insulin and diabetes products and into cardiovascular disease risks facing related patient groups: those with chronic kidney disease and high levels of inflammation. Corvidia's phase $2 \mathrm{~b}$ ziltivekimab, administered as a once-monthly subcutaneous injection, targets interleukin-6, an inflammatory cytokine.

Gilead's duo of private immunotherapy deals in mid-2020 aren't quite full acquisitions yet: it acquired just $49.9 \%$ each of private Pionyr Immunotherapeutics and Tizona Therapeutics for $\$ 275$ million and $\$ 300$ million up front, respectively. But Gilead has the option to purchase the rest of both companies for over a billion more.

Both deals further Gilead's quest for a next generation of cancer checkpoint inhibitors: Pionyr's antibodies-its lead is in phase $1 \mathrm{~b}$-target TREM1 and TREM2, proteins found on the surface of myeloid cells involved in suppressing immune response to cancer; Tizona's antibody TTX-080, entering the clinic, targets human leukocyte antigen G (HLA-G), an immune checkpoint found across several tumor types. But in the end, these were just the warm-up to Gilead's giant $\$ 21$ billion purchase of (public) Immunomedics, which happened weeks later.

\section{A reckoning looms?}

It's hard to find bad news in these numbers. Some investors worry about overfunded biotechs spending capital inefficiently, as well as the risk of down rounds (funding rounds that assume a lower company valuation than in an earlier financing). Inevitably, bad news and/or any cool-off in public market sentiment may reduce liquidity (the ability to quickly sell investments for cash). This could scare off some of the more generalist hedge fund and asset manager types that are new to the sector.

For now, conditions remain very healthy. When biotech began its surge last April after the market rout, the only thing investors imagined could spoil the party was damage to the wider economy. Things did go horribly wrong-lockdowns were chaotic and new coronavirus variants emerged. Still biotech flourished. R\&D was disrupted for a while, and some investors culled their portfolios more quickly than they otherwise might have. But now, "our [laboratory/discovery] activity is back to the same as it was prepandemic," says Third Rock's Tong. "We have adapted to a new normal."

Flexible, supportive drug regulators and a sense that the pandemic has pushed aside policies to curb drug prices add to the spirit of confidence. Yet those pricing concerns will re-emerge-and their impact will trickle down to biotech. There is growing recognition that most health systems are ill-equipped to pay for the slew of innovative therapies, including potentially curative but highly expensive cell and gene therapy solutions (Box 2). The low interest rates and generous government support in some countries that have helped fuel the markets cannot endure.

Hence no experienced biotech investor is assuming this funding party will last. "People realize this is a unique environment," says Tong. Biotechs are right to make the most of it; and the more capital that flows in, the greater the cushion against future shocks. But, warns Malik, "at some point, there will be a reckoning."

\section{Melanie Senior}

London, UK.

Published online: 1 April 2021

https://doi.org/10.1038/s41587-021-00876-w 